\title{
Spatial distribution, sources and bio-environmental risk appraisal of heavy metals in surface sediments from north western Karnataka, south India
}

Ishfaq Ahmad Mir ( $\square$ geoishfaq@gmail.com )

Geological Survey of India

SreePrabash M

Geological Survey of India

Sridhar V

Geological Survey of India

Maruthi KV

Geological Survey of India

\section{Research Article}

Keywords: Sediments, heavy metals, contamination, ecological risks, multivariate statistics

Posted Date: February 28th, 2022

DOI: https://doi.org/10.21203/rs.3.rs-1254700/v1

License: @ (i) This work is licensed under a Creative Commons Attribution 4.0 International License.

Read Full License 


\section{Abstract}

This study presents spatial distribution, sources and toxicological risks of $\mathrm{As}, \mathrm{Cr}, \mathrm{Cu}, \mathrm{Hg}, \mathrm{Ni}, \mathrm{Pb}$, and $\mathrm{Zn}$ in the surface sediments from north-western Karnataka, southern India. Heavy metals (except $\mathrm{Hg}$ ) are 1-5 times enriched than upper continental crust. High concentration of $\mathrm{Cr}, \mathrm{Ni}, \mathrm{Cu}$, and $\mathrm{Zn}$ is in the central Kudalgaon, Devarayi, and Tavargatti and in the south-western Ganeshgudi area, whereas Arsenic is enriched in the north-eastern Alnavar, Kakkeri,Tavargatti and $\mathrm{Pb}$, and $\mathrm{Hg}$ in the north-western Kapoli, Devarayi, Manjarpal villages. The ecological risk index, toxic risk index, and mean probable-effects-levels quotient of heavy metals suggest that $\sim 40 \%$ of the area is prone to very high risk especially for $\mathrm{Cr}$ and $\mathrm{As}$ to the hydrological, biological, and ecological systems. Multivariate statistical analysis suggests possible geogenic sources for $\mathrm{Ni}, \mathrm{Cr}, \mathrm{Cu}$, and $\mathrm{Zn}$ and anthropogenic sources such as emissions from vehicles and agricultural sectors for $\mathrm{As}, \mathrm{Hg}$, and $\mathrm{Pb}$. This study is the first of its kind in the area, which will help, in better formulation of environmental pollution and risk related remedial measures to conserve the natural ecosystem and the well-being of humans.

\section{Highlights}

- Arsenic and $\mathrm{Cr}$ are the most serious toxins in surface sediment of the Belgaum, Dharwad, and Uttar Kannada area.

- The high potential risk areas are situated in central, north-eastern, and south-western parts of the study area.

- $\mathrm{Cr}, \mathrm{Cu}, \mathrm{Ni}$, and $\mathrm{Zn}$ are mostly derived from geogenic sources and $\mathrm{As}, \mathrm{Hg}$, and $\mathrm{Zn}$ are mostly contributed by anthropogenic activities.

\section{Introduction}

Essential micro-nutrients are required for the functioning of living beings; however, an excess amount of these elements produce cellular and tissue damage leading to a variety of adverse diseases in humans and harmful effects in plants and other animals (Oves et al., 2012). Heavy metals (HM's) like As, Cd, Cr, $\mathrm{Pb}$ and $\mathrm{Hg}$ (Tchounwou et al., 2008) have a higher degree of toxicity, making these 5 metals a top priority for public health concerns. Since the last decade, there is a great awareness in the scientific community about public health and environmental risks associated with $\mathrm{HM} \Downarrow \mathrm{s}$ pollution form increased industrial processes, agricultural activities, combustion, electronic applications, and municipal waste (Bradl, 2002; Inigo et al., 2013). Even at lower levels of exposure, the toxicity of HM囚s is known to induce multiple organ damage.

Surface sediments on planet Earth receive a huge amount of pollutants every year from various geogenic and anthropogenic sources, making soil components not only as a pollutant sink but also act as a buffer by controlling the transport of pollutants in the environment (Kabata-Pendias and Pendias, 2001). High concentrations of $\mathrm{As}, \mathrm{Cr}, \mathrm{Cd}, \mathrm{Hg}$, and $\mathrm{Pb}$ in soil are toxic to most plants and animals. 
In the Karnataka state of south India, $16 \%$ share in gross domestic production (GDP) is contributed by the agriculture sector, which is higher than the national average (Deviprasad et al., 2015). Pesticide and fertilizer use in agriculture fields is the key control strategy for controlling crop diseases and improving crop yields. However, in recent years, concern has been growing on the improper usage of hazardous agrochemicals (Gupta, 2004). Agro-chemical overdoses are creating health issues such as skin problems,

eye irritation symptoms, breathing problems, dehydration, vomiting, cramps, and diarrhoea in the farming community (Deviprasad et al., 2015).

Geochemical mapping was carried out in toposheet no. 48I/11 with an objective to prepare a multielement geochemical database finding its use in mineral resource development, land use planning, agriculture, forestry, environmental monitoring, human and animal health, and proper waste disposal. The present study based on seven heavy metals ( $\mathrm{As}, \mathrm{Cr}, \mathrm{Cu}, \mathrm{Hg}, \mathrm{Ni}, \mathrm{Pd}$, and $\mathrm{Zn}$ ) from surface sediments to provides a broader view for concentration, distribution, enrichment, sources and potential environmental risks of these heavy metals.

\section{Study area}

The area lies between $15.25^{\circ} \mathrm{DD}$ to $15.50^{\circ} \mathrm{DD}$ latitudes and $74.50^{\circ} \mathrm{DD}$ to $74.75^{\circ} \mathrm{DD}$ ) longitudes (Figure1) in the northwestern part of Karnataka State, South India, covering parts of Belgaum, Dharwad and Uttar Kannada districts. The western side of the area is hilly terrain with steeply rising hills and narrow valleys and the eastern side is a plain landform, the major drainage pattern of the area is dendritic. The area lies in the Western Dharwar Craton (WDC) of Indian shield and is occupied by gneissic rocks of Peninsular Gneissic Complex (PGC); quartzite, limestone, phyllite, argillite, banded iron formation, and schist rocks of Dharwar Supergroup of Shimoga schist belt and dolerite dykes of Younger Intrusives Group. The PGC forms much of the WDC and is made up of tonalitic-trondhjemitic gneiss with many inclusions of older sedimentary and igneous rocks (Figure-2, Bhat et al., 2021). Local climate is mainly warm semi-arid, "BSh class" (Koppen, 1884) and annual average temperature and rainfall is $24.3^{\circ} \mathrm{C}$ and $885 \mathrm{~mm}$ respectively. Isolated patches in the entire area and all of the north-eastern part is occupied by human settlements and is under cultivation of sugarcane, rice, cotton, and mango; the remaining part of the area is covered by forests (Figure-3, Bhat et al., 2021).

Figure 1 is here

Figure 2 is here

Figure 3 is here

\section{Materials And Methods} Sampling 
Geochemical mapping on the 1:50,000 scale was carried out by following the standard operating procedure (SOP, 2014) of the National Geochemical Mapping (NGCM) program of the Geological Survey of India (GSI). During field session 2017-18, in $756 \mathrm{~km}^{2}$ areas a total of 752 surface sediments samples (stream sediment and slope wash) on $1 \times 1 \mathrm{~km} .{ }^{2}$ grid pattern and 9 duplicate samples on $5^{\prime} \times 5^{\prime} \mathrm{km} .{ }^{2} \mathrm{grid}$ pattern were collected (Figure-1). Duplicate samples were collected for cross-check analysis. In individual unit cells, fine sediments (silt/clay) were collected within a 100-meter distance at few locations from 1st order streams. Slope wash samples were collected where stream sediments were not available. Samples were sun-dried followed by sieving using -120 size nylon cloth. All samples ( $<75 \mu \mathrm{m}$ grain size) were coned and quartered and 195 composite samples (each representing $2 \mathrm{~km} \times 2 \mathrm{~km}$ grid.) were prepared from the entire toposheet for geochemical analysis.

\section{Heavy metal analysis}

195 composite samples were analysed for $\mathrm{Cr}, \mathrm{Cu}, \mathrm{Ni}, \mathrm{Pb}, \mathrm{Zn}$ with major oxides (\%) and few trace elements (ppm) using X-ray fluorescence (XRF) facility (Make and Model: M/S Pananalytical; MAGIX, 2.4 KW Sequential XRF Spectrometer) at GSI, chemical laboratory, Hyderabad. About $5 \mathrm{~g}$ of sample powder (-200 mesh) was spread in the aluminium cup (40 $\mathrm{mm}$ diameter in size) over the boric acid powder (AR Grade) and pressed into a pellet under a pressure of 20 tons with the help of a hydraulic press pellet machine to get a uniform pressed pellet. The sample pellet was kept in the sample cup of the XRF unit for elemental analysis. Standard reference material (SRM) (GBW-07312) was analysed after each batch of 20 samples for accuracy and duplicate samples after each batch of 10 samples for repeatability. The accuracy and precision of the measurements were within $\pm 2 \%$.

Arsenic concentration in the collected samples was measured using Flow Injection Analysis SystemAtomic Absorption Spectrophotometer (FIAS-AAS) instrument at GSI, Chemical laboratory, Hyderabad, (make \& model: PERKIN-ELMER ANALYST-100). About $0.25 \mathrm{~g}$ of sample (-200 mesh) was digested with an acid mixture in the ratio of 2:2:1 $\mathrm{ml}\left(\mathrm{HNO}_{3}+\mathrm{HClO}_{4}+\mathrm{HF}\right)$ and few drops of $10 \% \mathrm{HCl}$ and then evaporated at $180-200^{\circ} \mathrm{C}$ to near drying and then again $1: 1 \mathrm{HCl}$ was added. The solution was analysed on FIAS-AAS. SRM (GSD-2a/3a/6) and duplicate samples were also analysed and the accuracy and precision was \pm $1 \%$.

Similarly, all composite samples were analysed for $\mathrm{Hg}(\mathrm{ppb})$ concentration using Direct Mercury Analyser (DMA) instrument at GSI, Chemical laboratory, Hyderabad, (make \& model: MILESTONE, DMA-80). The samples were ground to -200 mesh particle size and then a $0.2 \mathrm{~g}$ sample was weighed into the quartz sample boat and analysed on DMA-80. SRM (GSS-2) and duplicate samples were also analysed and the accuracy was $\pm 4 \%$ and precision was $\pm 3 \%$.

\section{Data processing, statistical analysis, and plotting}

Mathematical calculations are performed using Microsoft Excel software. Statistical analysis, bivariate plots, and spatial distribution maps are prepared using Origin-Pro 2016 software. 
To evaluate the magnitude of contamination in the surface sediments and their potential bioenvironmental risks, four indices were calculated: enrichment factor (EF), ecological risk index (ERI), toxic risk index ( $\sum$ TRI), and mean probable-effects-levels quotient (M-PEL-Q).

Descriptive statistical parameters (Table-1) such as minimum, maximum, mean, skewness, kurtosis, standard deviation, and variance were computed for top soil samples to make a comparison with the upper continental crust (UCC, Taylor and McLennan, 1985). The spatial distribution of the contaminants and their potential bio-environmental risks and were plotted by using 3D mapping methods of OriginPro 2016 software for Windows. To determine the relationship between the HM囚s and their probable sources, multivariate statistical analyses were performed. In this study, Pearson's correlation matrix (PCM, Figure7) and hierarchical cluster analysis (HCA, Figure-7a) were used. The dendrogram is derived from the HCA of heavy metals in analyzed surface sediment samples, the cluster method used is the nearest neighbour, and the distance type is an absolute correlation. PCM and HCA are used to investigate the similarities between element patterns from surface sediment samples and the provenance of these contaminants.

\section{Table 1 is here}

\section{Results}

The concentration of $\mathrm{HM} \varangle \mathrm{s}$ in stream sediments is shown in Figure-4a and the spatial distribution of samples having the highest content of metals in the entire area is shown in Figure-4b. Descriptive statistics along with crustal averages are provided in Table-1 (supplementary data 1). The absolute concentration of HM's showed 4-20 order of variability with an average value of 168, 50, 21, 34, 76 and $25.6 \mathrm{ppm}$ for $\mathrm{Cr}, \mathrm{Ni}, \mathrm{Pb}, \mathrm{Cu}, \mathrm{An}$ and $\mathrm{Hg}$ respectively. Arsenic concertation showed the greatest variability among all the analyzed HM's of the order 74 with an average value of $25.6 \mathrm{ppm}$. The average concertation values of $\mathrm{HM} 囚 \mathrm{~s}$ (except $\mathrm{Hg}$ ) in sediments are significantly enriched than the average upper crust.

Samples from the centre of the study area between Kudalgaon, Devarayi, and Tavargatti villages and in the south-western part near Ganeshgudi village shows higher $\mathrm{Cr}$ abundance (1177 ppm) (Figure-2). The distribution of $\mathrm{Cr}$ overlap with $\mathrm{Ni}$ and is very similar to the distribution pattern of $\mathrm{Cu}$ and $\mathrm{Zn}$ (Figure-4), indicating almost similar origins for these metals. In this area, there is no agricultural or major human activity suggesting the mostly geogenic origin of these metals. The granite gneiss, banded iron formation, and magniferrous phyllite (Figure-2) are the major rock types exposed in this area could be probable sources of these metals. In contrast top soil samples from north-eastern part of the study area between Devarayi, Merda, Kakkeri, and Alnavar villages (Figure-4) showed mainly Arsenic enrichment. In this area, there is extensive sugarcane, rice, and mango farming depends heavily on groundwater for irrigating the farmland. The argillite of Shimoga schist belt and granite gneiss (Figure-2) are the rock types exposed in this area.

A higher concentration of $\mathrm{Pb}(56 \mathrm{ppm})$ and $\mathrm{Hg}(103 \mathrm{ppb})$ (Figure-4) prevailed in the north-western part of the study area between Manjarpal and Kapoli villages (Figure-2). Granite gneiss (Figure-2) constitute the 
major lithological unit exposed in this area.

Figure 4 is here

\section{Discussion}

\section{Enrichment Factor (EF)}

EF (Simex and Helz, 1981) is calculated by relating the metal (M) concentration in samples with that of Earth's crust (Taylor and McLennan, 1985). In this study, Fe is considered as reference (Simex and Helz, 1981) and EF is calculated by using the following equation:

$\mathrm{EF}=(\mathrm{M} / \mathrm{Fe})_{\text {sample }} /(\mathrm{M} / \mathrm{Fe})$

The EF is used to discriminate between natural versus anthropogenic sources. The EF value close to 1 generally indicates geogenic source for HM's and EF value > 1.5 suggests anthropogenic contribution from non-crustal materials (Zhang and Liu, 2002). EF analysis cannot exactly assess the degree of contamination in the natural environment, it broadly classifies the geogenic or anthropogenic sources of the pollutants and the role of human activities, climate, weathering, erosion, and other sedimentary processes involved in the distribution of the metals (Reimann and de Caritat, 2005). Geochemical surveys indicate that EF of metals in soils is influenced by various natural and anthropogenic processes and contamination is one of the factors (Reimann and de Caritat, 2005). EF of HM $₫$ s calculated showed low to high enrichment for As (0.18-25.47) and $\mathrm{Cr}$ (1.02-21.78), low to moderate enrichment for $\mathrm{Ni}$ (1.097.09) and $\mathrm{Pb}(0.18-4.74)$ and low enrichment similar to crust for $\mathrm{Cu}(0.49-3.16), \mathrm{Zn}(0.24-2.43), \mathrm{Hg}$ (0.15-1.84) suggesting $\mathrm{As}, \mathrm{Cr}$ and $\mathrm{Ni}$ as the major pollutants of concern in the study area. Spatial distribution mapping of EF (Figure-5) showed significant to very high EF values for Arsenic in the northeastern, northern, and western parts of the study area overlaps with the area under agriculture practices of sugarcane, rice, and mango farming. Excessive application of pesticides and fertilizers for higher crop yield and disease protection and extensive groundwater pumping for irrigation would have resulted Arsenic enrichment. The EF of Arsenic shows no overlap with the local geology, indicating the anthropogenic sources of Arsenic contamination. On the other hand, significant to very high EF values for $\mathrm{Cr}$ in the northern, central, and western parts of the study area overlaps with the area covered by granite gneiss rocks. Further, $\mathrm{EF}$ of $\mathrm{Cr}$ values do not overlap with the agricultural field area, indicating geogenic sources for $\mathrm{Cr}$ contamination (granite gneiss). Arsenic and $\mathrm{Cr}$ exhibited a weak correlation with each other $(0.04$, Figure-7b) confirmed different sources of these toxic metals, most probably pesticides, fertilizers and groundwater irrigation for Arsenic and local granite gneissic rocks for $\mathrm{Cr}$.

The distribution of As ( $\mathrm{ppm}$ ) in not matching with lithology (Figure-4) suggesting a mostly anthropogenic origin. Arsenic rich pesticides and overexploitation of groundwater are the probable anthropogenic sources of $\mathrm{As}(\mathrm{ppm})$ in this area. The distribution of $\mathrm{Pb}$ and $\mathrm{Hg}$ in the sediments also does not match with lithology (Figure-4) suggesting a mostly anthropogenic origin for these metals. Ongoing intense 
illegal mining for construction material in this region suggests a predominant anthropogenic origin for $\mathrm{Pb}$ and $\mathrm{Hg}$. Emissions from machines and vehicles used in the extraction of construction material and its transportation could be the probable sources of $\mathrm{Pb}$ and $\mathrm{Hg}$.

\section{Figure 5 is here}

\section{Ecological Risk Index ( $\sum$ ERI)}

ERI (Hakanson, 1980) considers the toxicity of all HM $₫$ s, ERI of a particular metal (i) is calculated by using the following equation:

$E R I=\operatorname{Tr}^{\mathrm{i}} \times \mathrm{Cf}^{\mathrm{i}}$

Where $\operatorname{Tr}^{i}$ is the biological toxic response factor of metal (i): $A s=10, C r=2, C u=5, N i=5, P b=5, Z n=1$, $\mathrm{Hg}=40)$ (Hakanson, 1980) and $\mathrm{Cf}^{\mathrm{i}}$ is the ratio between geological background $\left(\mathrm{Cn}^{\mathrm{i}}\right)$ and recent sediment (Ci) concentration. The sum of ERI of individual metals is the potential risk ( $\left.\sum E R I\right)$ for the water bodies of the area of investigation and is calculated by using the following equation:

$\sum E R I=\sum\left(\operatorname{Tr}^{\mathrm{i}} \times \mathrm{Cf}^{\mathrm{i}}\right)$

In this study, $\sum$ ERI presented is calculated according to the terminology used by Liu et al. (2012), $\sum$ ERI is calculated from the individual ERI of 7 metals of the surface sediments. $\sum$ ERI (Liu et al., 2012) distribution in the study area is calculated from the summation of individual ecological risks (Hakanson, 1980) of $\mathrm{Ni}, \mathrm{Pb}, \mathrm{Cr}, \mathrm{Cu}, \mathrm{Zn}, \mathrm{As}$, and $\mathrm{Hg}$ (Figure-6a). The spatial pattern of individual ERI $₫$ s however shows strong similarity with EF results (Figure-5a). The individual ERI『s plots do not give a better toxicity picture of the area. To overcome this problem, a quick and simple method $\sum E R I$ is used for evaluating the level of pollution (Kang et al., 2018). This method classifies the study area into a different levels of contamination zones and identifies the high toxic area for necessary actions (Fiori et al., 2013). This method despite developed for lacustrine systems is still widely used by researchers on land pattern contaminations also (Liu et al., 2012; Fiori et al., 2013; Kang et al., 2018). The model is formulated based on simple algorithms, has an organized structure including the mathematical relationships between the environmental parameters. The $\sum E R I$ is based on the heavy metal chemistry of surface sediments from the surroundings of aquatic systems. Surface sediment sampling and their chemical analysis are easier than water, and are more representative for spatial and temporal distribution. The sediment geochemical data provides a high concentration of contaminants with higher stability than water thereby reducing the possibility of errors due to detection limits of the analytical methods applied.

$\sum$ ERI is moderate to considerable (94-303) in about $60 \%$ of the area and is low (38-94) in about $40 \%$ of the area. Water bodies (Supa dam reservoir and Kali river) around Ganeshgudi-Jagalbet villages in the south-western part, around Devarayi-Manjarpal villages in the north-western part, and Kakkeri-AlnavarMangalvad villages in the north-eastern part of the study area show a moderate to a high level of potential ecological risk for the aquatic system and their biota. The dense forest stretch from north to south between Merda-Dandeli villages (Figure-2) in the middle part of the study area is almost free from 
human encroachment and anthropogenic activities. The distribution of low $\sum$ ERI values overlaps with this dense forest area. The highest values of $\sum E R I$ around Ganeshgudi village could be due to the Supa dam reservoir-related anthropogenic activities and around Alnavar village could be due to the settlementrelated anthropogenic activities such as vehicle emissions, agriculture, construction and domestic waste. The low-risk zone in the middle dense forest area is habituated by few tribal villages that live in close harmony with nature.

\section{Toxic Risk Index ( $\left.\sum \mathrm{TRI}\right)$}

TRI (Zhang et al., 2016) considers the threshold-effect-level (TEL) and probable-effects-levels (PEL) of metals to assess the biological risks. The individual toxic risk index (TRli) is calculated by using the following equation:

TRli $=\sqrt{(C i / T E L})^{2}+(\mathrm{Ci} / \mathrm{PEL})^{2} / 2$.

Where $\mathrm{Ci}$ is the ratio between geological background and surface sediment metal concentration, TEL of the metals is $\mathrm{As}=5.9, \mathrm{Cr}=37.3, \mathrm{Cu}=35.7, \mathrm{Ni}=18, \mathrm{~Pb}=35, \mathrm{Zn}=123, \mathrm{Hg}=0.17$ ) (Zhang et al., 2016) and $\mathrm{PEL}$ of the metals is $\mathrm{As}=17, \mathrm{Cr}=90, \mathrm{Cu}=197, \mathrm{Ni}=26, \mathrm{~Pb}=91.3, \mathrm{Zn}=315, \mathrm{Hg}=0.486$ ) (Zhang et al., 2016). The sum of individual TRli of metals is the potential toxicity risk index ( $\sum$ TRI) for the sediments and is calculated by using the following equation:

$\sum \mathrm{TRI}=(\mathrm{TRli} 1+\mathrm{TRli} 2+\ldots \ldots . . . \mathrm{TRli} 7)$.

The toxic units (TUs) of HM囚s consider only the probable effect level (PEL) (Pedersen et al., 1998) and ignores the threshold effect level (TEL) to calculate the ecological toxicity. Using only PEL values, this equation underestimates the ecological toxic risk, to overcome this problem Zhang et al., (2016) developed a new toxic risk index (TRI) integrating both TEL and PEL based toxic levels of HM囚s in the surface sediments and their potential risks to the aquatic organisms (Eq. 4). The individual toxic risk index (TRli) of metals in this study are significantly variable for $\mathrm{Ni}(0.74-15.19), \mathrm{Pb}(0.23-1.21), \mathrm{Cr}$ (0.94-24.15), $\mathrm{Cu}(0.20-2.93), \mathrm{Zn}(0.10-1.10), \mathrm{As}(0.063-4.68)$ and $\mathrm{Hg}(0.039-0.45)$. TRli in the sediments is below 5 for $\mathrm{Pb}, \mathrm{Cu}, \mathrm{Zn}$, As and $\mathrm{Hg}$ suggesting absence of any toxic risk and above 5 for $\mathrm{Ni}$ and $\mathrm{Cr}$ indicating presence of toxic risk of these metals to the aquatic life. The ecological toxicity classification based on integrated toxic risk ( $\sum$ TRI, Eq. 5) values are shown in Figure-6b, which summarized toxic risk index to provide a better picture of toxicity risks. The $\sum$ TRI in the study area varies from $3.38-37.10$, and $\sim 60 \%$ of the area has $\sum$ TRI $<5$ indicating no toxicity, and the remaining $\sim 40 \%$ of the study area has a low to very high risk of toxicity. Spatially the $\sum$ TRI of the HM『s is highest in the central (Kudalgaon-Tavargatti-Devarayi region), south-western (Ganeshgudi region), and north-eastern (Kakkeri area) (Fig. 6b). $\mathrm{Cr}$ and $\mathrm{Ni}$ are the highest contributors, whereas $\mathrm{As}, \mathrm{Cu}, \mathrm{Pb}, \mathrm{Zn}$, and $\mathrm{Hg}$ have lowest contribution to $\sum$ TRI. Contaminated sediments in high toxic risk areas need to be given more attention due to their high contributing ratios to $\sum$ TRI.

\section{Mean Probable-Effects-Levels Quotient (M-PEL-Q)}


M-PEL-Q (Gu, 2018) considers the mean probable-effects levels (PEL) to determine the biological effects and potential ecological risk of the HM『s. The M-PEL-Q is calculated by using the following equation:

M-PEL-Q $=(\mathrm{Ci} / \mathrm{PELi} 1+\mathrm{Ci} / \mathrm{PELi} 2+$ Ci/PELi7).

Where $\mathrm{Ci}$ is the ratio between geological background and surface sediment metal concentration and PEL of the metals is $\mathrm{As}=17, \mathrm{Cr}=90, \mathrm{Cu}=197, \mathrm{Ni}=26, \mathrm{~Pb}=91.3, \mathrm{Zn}=315, \mathrm{Hg}=0.486$ ).

Quality of top soil accessed by mean probable-effects-levels quotient method (M-PEL-Q; Gu, 2018) is a useful tool to decipher the impact of heavy metal pollution on aquatic life (Long and Macdonald, 1998). The M-PEL-Q uses the combined effects of heavy metals (Eq. 6) considering PEL values to calculate the potential biological and ecological risks. The M-PEL-Q values in the study area vary from $0.23-2.98$ (Figure-6c), indicating $\mathrm{HM} \backslash \mathrm{s}$ are posing $21-73 \%$ toxic effect on the hydro-biology. Spatially $\sim 50 \%$ of the area is having moderate $(21 \%), \quad 30 \%$ of the area is having significant $(49 \%)$, and $\sim 20 \%$ of the area is having high $(73 \%$ ) chances of toxicity on biology (Figure-6c). The M-PEL-Q value of $<1.0$ (Long et al., 1995 ) is usually considered to be safe, and does not require any action to be taken. In this study, M-PEL-Q values for the entire area vary from $0.23-2.98$, with $\sim 60 \%$ of the area having M-PEL-Q value $<1.0$ which is under safe limit. The remaining $\sim 40 \%$ of the field area has an M-PEL-Q value between 1.0-2.98 is above the safe limit, and can pose moderate to high (21-73\%) biological and ecological risks which needs urgent action to prevent further deterioration. The M-PEL-Q and $\sum$ TRI (Zhang et al., 2016) have similar distribution pattern suggesting that both methods are an acceptable tool for the assessment of biological and ecological toxicity risks for sediments, vegetation, aquatic and terrestrial organisms and human beings.

Based on the results of these four assessment methods, $40 \%$ of the surface sediments, water bodies, and the ecology in the Belgaum, Dharwad, and Uttar Kannada districts of Karnataka state of India can be described as having moderate to high pollution risk posed by $\mathrm{HM} \llbracket s$ and requires urgent attention of policymakers and the general public from further environmental and human health deterioration. Anthropogenic sources of contamination such as excessive use of pesticides, fertilizers, automobile emissions, and over-exploitation of groundwater need to be reduced. The area with the high potential for biological, hydrological, and environmental risks caused by anthropogenic contamination is mainly concentrated in the north-eastern agriculture belt surrounding the Alnavar village and in the south-western area surrounding Ganeshgudi village near Supa dam reservoir. The rest of the study area is having low to moderate toxic risks and is under safe zone. As and $\mathrm{Cr}$ are the high-risk toxic elements, $\mathrm{Ni}$ is the considerable risk toxic element, and $\mathrm{Pb}, \mathrm{Cu}, \mathrm{Zn}$, and $\mathrm{Hg}$ are the low-risk toxic elements in the study area. $\mathrm{Cr}$ and $\mathrm{Ni}$ contamination is broadly contributed by natural processes and Arsenic contamination is mainly contributed by human activities. The $\sum \mathrm{TRI}$ and mean probable-effects-levels quotient $(\mathrm{Gu}, 2018)$ showed good correlation with each other suggesting that the TRI is an acceptable accurate method for the assessment of ecological toxicity.

Figure 6 is here 
Identifying the sources of metals.

Multivariate statistical analysis methods of hierarchical cluster analysis (HCA, Figure-7a) and Pearson's correlation matrix (PCM, Figure-7b) are performed to identify the origin, similar behavior, and distribution of $\mathrm{HM} \Downarrow \mathrm{s}$ in the study area. HCA identified five groups (G1-5) of association between seven HM $\llbracket \mathrm{s}$ (Figure7a) used in this study. G-1 consisting of $\mathrm{Ni}$ and $\mathrm{Cr}$, and G-2 consisting of $\mathrm{Cu}$ and $\mathrm{Zn}$ indicates that these metal groups are derived from similar sources. G-3 consists of $\mathrm{Hg}, \mathrm{G}-4$ consists of $\mathrm{Pb}$ and $\mathrm{G}-5$ consists of Arsenic suggests that these metal groups are derived from different sources. G-1 and G-2 are possibly originating from geogenic sources through the weathering of parent material as their higher concentrations overlap with the geology but not with the land-use distribution.

Probable sources of groups $\mathrm{G}-1$ ( $\mathrm{Ni}=17$ to $346 \mathrm{ppm}$ and $\mathrm{Cr}=46$ to $1177 \mathrm{ppm}$ ) seems to be derived from gneissic rocks and for $\mathrm{G}-2(\mathrm{Cu}=10$ to $146 \mathrm{ppm}$ and $\mathrm{Zn}=17$ to $179 \mathrm{ppm})$ metals from Joldal and PGC Formations due to similarity in distribution pattern with local geology. G-3 ( $\mathrm{Hg}=9$ to $103 \mathrm{ppb}), \mathrm{G}-4$ ( $\mathrm{Pb}=$ 11 to $56 \mathrm{ppm}$ ), and G-5 (As $=0.5$ to $36.9 \mathrm{ppm}$ ) are possibly originating from anthropogenic sources as their higher concentrations overlap well with the land-use distribution but not with the geology of the area. $\mathrm{Hg}$ and $\mathrm{Pb}$ seems to be originating from atmospheric emissions of automobiles, and agricultural machines. High Arsenic content is sediments of the north-eastern side is consistent with large scale sugarcane plantation and excessive groundwater pumping for better crop yield. Arsenic rich pesticides and overexploitation of groundwater are therefore possible source of Arsenic contamination in the surface sediments. The use of pesticides, fertilizers, and other anthropogenic activities will also be contributing to the heavy metal pollution in the Belgaum, Dharwad, and Uttar Kannada districts of Karnataka state, but are beyond the scope of the present study. Correlation analysis (PCM) also indicates a similar observation. $\mathrm{Ni}, \mathrm{Cr}, \mathrm{Cu}$, and $\mathrm{Zn}$ showing strong positive correlation $(0.59-0.81)$ with each other suggests similar geological sources and weak correlation with $\mathrm{Hg}, \mathrm{Pb}, \mathrm{As}(-0.04-0.26)$ suggests different sources. $\mathrm{Hg}, \mathrm{Pb}$, and As further showing weak correlation (-0.04-0.28) with each other indicates different anthropogenic sources.

Figure 7 is here

\section{Conclusions}

Heavy metal study in the surface sediments was conducted in the Belgaum, Dharwad, and Uttar Kannada districts of Karnataka, India to decipher the level of contamination and potential biological and ecological risks. The average concentration of studied metals is higher than crustal averages except for $\mathrm{Hg}$. It is evident that the topsoil samples in the studied region exhibit significant to very high enrichment for As and $\mathrm{Cr}$ and minimum to moderate enrichment for $\mathrm{Ni}, \mathrm{Pb}, \mathrm{Cu}, \mathrm{Zn}$, and $\mathrm{Hg}$. Higher concentrations of $\mathrm{Cr}, \mathrm{Ni}$, $\mathrm{Cu}$, and $\mathrm{Zn}$ observed in and around the central and south-western part, whereas Arsenic in the northeastern part and $\mathrm{Pb}$, and $\mathrm{Hg}$ in the north-western part of the study area. The application of the ecological risk index, toxic risk index, and mean probable-effects-levels quotient suggest elevated contents of toxic metals ( $\mathrm{Ni}, \mathrm{Pb}, \mathrm{Cr}, \mathrm{Cu}, \mathrm{Zn}, \mathrm{As}, \mathrm{Hg}$ ) which are posing moderate to high hydrological, biological, and 
ecological risks in $\sim 40 \%$ of the area and low to moderate risks in rest of the area. Hierarchical cluster analysis deployed for source identification revealed possible geogenic sources for $\mathrm{Ni}, \mathrm{Cr}, \mathrm{Cu}$, and $\mathrm{Zn}$ and anthropogenic sources for $\mathrm{As}, \mathrm{Hg}$, and $\mathrm{Pb}$. As is possibly contributed by Arsenic rich pesticides and overexploitation of groundwater for irrigation purposes. $\mathrm{Hg}$ and $\mathrm{Pb}$ possibly are contributed by atmospheric emissions coming from automobiles and agriculture machines. The correlation matrix of heavy metals also provides a similar picture to that of cluster analysis. In summary, it can be concluded from observed results that surface sediments in the studied region is highly contaminated by $\mathrm{Cr}$ and As and moderately contaminated by $\mathrm{Ni}, \mathrm{Pb}, \mathrm{Cu}, \mathrm{Zn}, \mathrm{Hg}$. Since this is the first heavy metal pollution study on surface sediments in the Belgaum, Dharwad, and Uttar Kannada districts of south India, more detailed studies are required to obtain adequate knowledge of the contamination levels and their potential risks for better land and water management and sustainable policies formulation.

\section{Declarations}

\section{Acknowledgment}

This work was financially supported by the Ministry of Mines, Govt. of India. The authors thank the Director-General, Geological Survey of India for formulating the national geochemical mapping program. The authors acknowledge the Additional Director General, Southern Region, Shri Janardan Prasad, and the Deputy Director-General, State Unit: Karnataka and Goa, Shri Debkumar Bhattacharya for technical support. Mir, I.A., express his sincere thanks to Shri. Anindya Bhattacharya for his constant support and encouragement.

\section{Data availability}

All data generated or analysed during this study are included in this published article (and its Supplementary Information files).

\section{References}

1. Bhat, A. A., Mir, I. A., SreePrabash M. \& Sridhar V. Final report on geochemical mapping in toposheet no. 48I/11 in Belgaum, Dharwad and Uttar Kannada districts, Karnataka. Geological Survey of India, open file report (2021).

2. Bradl, H. Heavy metals in the environment: origin, interaction, and remediation. Volume 6 , London: Academic Press (2002).

3. Chang, L. W., Magos, L. \& Suzuki, T. Toxicology of metals. Boca Raton. FL, USA: CRC Press (1996).

4. Cristiane da Silveira Fiori et al. Ecological risk index for aquatic pollution control: a case study of coastal water bodies from the Rio de Janeiro State, south-eastern Brazil. Geochimica Brasiliensis 27, 24-36 (2013).

5. Deviprasad, A. G., Radha, S. \& Manonmani, H. K. Pesticide usage pattern in four districts of Karnataka: A survey. IOSR J. of Env. Sci., Tox. and Food Tech. 9, 48-51 (2015). 
6. Duffus, J. H. Heavy metals a meaningless term. Pure Appl. Chem. 74, 793-807 (2002).

7. Ernst, W. O. The origin and ecology of contaminated, stabilized, and non-pristine soils, metal contaminated soil. Springer, New York, NY, USA (1998).

8. Fergusson, J. E. The heavy elements: chemistry, environmental impact, and health effects. Oxford: Pergamon Press (1990).

9. Cuadrado, C., Kumpulainen, J., Carbajal, A. \& Moreiras, O. Cereals contribution to the total dietary intake of heavy metals in Madrid, Spain. J. Food Compos. Anal. 13, 495-503 (2000).

10. Gupta, P. K. Pesticide exposure - Indian scene. Toxicology, 198, 83-90 (2004).

11. Gu, Y. G. Heavy metal fractionation and ecological risk implications in the intertidal surface sediments of Zhelin Bay, South China. Mar. Pollut. Bull. 129, 905-912 (2018).

12. Hakanson, L. An ecological risk index for aquatic pollution control: a sedimentological approach. Water Res. 14, 975-1001 (1980).

13. Hashmi, N. M. Z. et al. Risk assessment of heavy metals pollution in agricultural soils of Siling reservoir watershed in Zhejiang Province, China. Bio Med Research International. Article ID 590306, http://dx.doi.org/10.1155/2013/590306 (2013).

14. He, Z. L., Yang, X. E. \& Stoffella, P. J. Trace elements in agro ecosystems and impacts on the environment. J. Trace Elem. Med. Biol., 19, 125-140 (2005).

15. Inigo, V., Andrades, M., Alonso-Martirena, J., Mar'ın, A. \& Jim'enez-Ballesta, R. Spatial variability of cadmium and lead in natural soils of a humid Mediterranean environment: La Rioja, Spain. Archives of Env. Cont. and Tox. 64, 594-604 (2013).

16. Kabata-Pendias, A. \& Pendias, H. Trace Elements in soils and plants. CRC Press, New York, NY, USA (2001).

17. Kang, X. et al. Historical trends of anthropogenic metals in sediments of Jiaozhou Bay over the last century. Mar. Pollut. Bull. 135, 176-182 (2018).

18. Koppen, W. The thermal zones of the earth according to the duration of hot, moderate, and cold periods and to the impact of heat on the organic world. Meteorologische Zeitschrift (published 2011) 20: $351-360$ (1884).

19. Long, E. R. \& Macdonald, D. D. Recommended uses of empirically derived, sediment quality guidelines for marine and estuarine ecosystems. Hum. Ecol. Risk Assess. Int. J. 4, 1019-1039 (1998).

20. Long, E. R., MacDonald, D. D., Smith, S. L. \& Calder, F. D. Incidence of adverse biological effects within ranges of chemical concentrations in marine and estuarine sediments. Environ. Manag.19, 81-97 (1995).

21. Mir, I. A. \& Mir, R. A. Geochemistry of surface sediments in parts of Bandipora-Ganderbal areas, Kashmir valley, Western Himalaya: Implications for provenance and weathering. J. Earth Syst. Sci. 128, 223:1-16 (2019).

22. Naila, A. et al. A review on global metal accumulators-a mechanism, enhancement, commercial application and research trend. Environ. Sci. Pollut. Res. 26, 26449-26471 (2019). 
23. Nriagu, J. O. A global assessment of natural sources of atmospheric trace metals. Nature, 19338:4749 (1989).

24. Oves, M., Khan, M.S., Zaidi, A. \& Ahmad, E. Soil contamination, nutritive value, and human health risk assessment of heavy metals: an overview, in toxicity of heavy metals to Legumes and Bioremediation, 1-27, Springer, New York, NY, USA (2012).

25. Pedersen, F., Bjørnestad, E., Andersen, H. V., Kjølholt, J. \& Poll, C. Characterization of sediments from Copenhagen Harbor by use of biotests. Water Sci. Technol. 37, 233-240 (1998).

26. Reimann, C. \& de Caritat, P. Distinguishing between natural and anthropogenic sources for elements in the environment: regional geochemical surveys versus enrichment factors. Sci. of the Total Env, 337, 91-107 (2005).

27. Simex, S. A. \& Helz, G. R. Regional geochemistry of trace elements in Chesapeake Bay. Environ. Geol., 3, 315-323 (1981).

28. Standard Operation Procedure for National geochemical mapping \& quality management. Revised and updated. Mission-l: Baseline Geosciences Data Generation of Geological Survey of India (2014).

29. Taylor, S. R. \& McLennan S. M. The continental crust: its composition and evolution; Blackwell, Oxford (1985).

30. Tchounwou, P. B., Yedjou, C. G., Patlolla, A. K. \& Sutton, D. J. Heavy metals toxicity and the environment. EXS; 101: 133-164. doi:10.1007/978-3-7643-8340-46 (2012).

31. Wang, K. et al. Mechanisms of $\mathrm{Cd}$ and $\mathrm{Cu}$ induced toxicity in human gastric epithelial cells: Oxidative stress, cell cycle arrest, and apoptosis. Sci. Total Environ., 14935. https://doi.org/10.1016/j.scitotenv.2020.143951 (2020).

32. Zhang, G. et al. Heavy metals in wetland soils along a wetland forming chronosequence in the Yellow River Delta of China: levels, sources, and toxic risks. Ecol. Indicat. 69, 331-339 (2016).

33. Zhang, J. \& Liu, C. L. Riverine composition and estuarine geochemistry of particulate metals in China-weathering features, anthropogenic impact, and chemical fluxes. Est., Coast. and Shelf Sci., 54, 1051-1070 (2002).

\section{Tables}

Table-1: Descriptive statistics of the studied heavy metals with their comparison to upper continental crust (UCC) Taylor and McLennan, (1985). 


\begin{tabular}{|lllllllll|}
\hline \multicolumn{2}{|l|}{ Descriptive Statistics } & & & & & & \\
\hline $\mathrm{N}=195$ & UCC & Minimum & Maximum & Mean & Skewness & Kurtosis & $\begin{array}{c}\text { Std. } \\
\text { Dev. }\end{array}$ & Variance \\
\hline $\mathrm{Ni}(\mathrm{ppm})$ & 20 & 17 & 346 & 50 & 4.9 & 32.8 & 34 & 1186 \\
\hline $\begin{array}{l}\mathrm{Pb} \\
(\mathrm{ppm})\end{array}$ & 20 & 11 & 56 & 21 & 1.6 & 3.9 & 7 & 44 \\
\hline $\mathrm{Cr}(\mathrm{ppm})$ & 35 & 46 & 1177 & 168 & 5.2 & 37.6 & 114 & 12936 \\
\hline $\begin{array}{l}\mathrm{Cu} \\
(\mathrm{ppm})\end{array}$ & 25 & 10 & 146 & 34 & 3.0 & 19.2 & 14 & 205 \\
\hline $\begin{array}{l}\mathrm{Zn} \\
(\mathrm{ppm})\end{array}$ & 71 & 17 & 179 & 76 & 1.5 & 4.0 & 24 & 552 \\
\hline $\mathrm{As}(\mathrm{ppm})$ & 1.5 & 0.5 & 36.9 & 7.6 & 1.4 & 2.8 & 7 & 47 \\
\hline $\mathrm{Hg}(\mathrm{ppb})$ & 50 & 9 & 103 & 25.6 & 2.8 & 12.9 & 11 & 125 \\
\hline $\mathrm{Fe} \mathrm{O}_{3}(\%)$ & 5 & UCC: Taylor and McLennan, (1985) & & & \\
\hline Figures & & & & & & & & \\
\hline
\end{tabular}

Figures

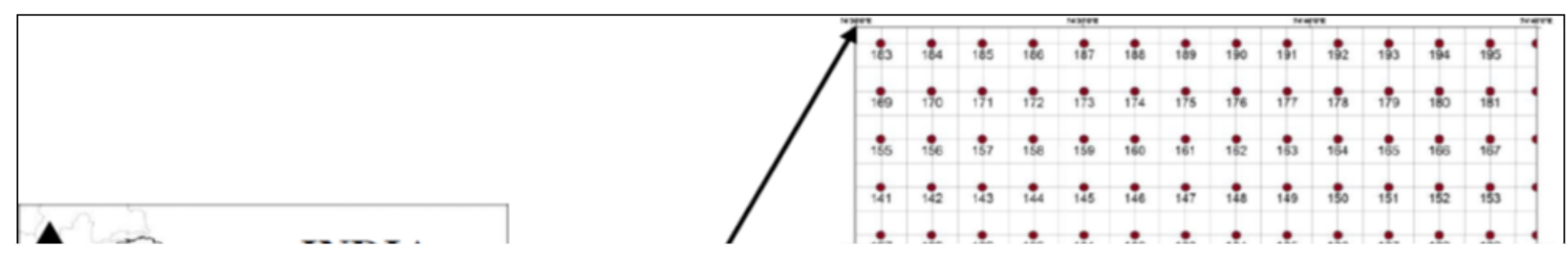

Figure 1

Location map of the study area and sampling points. 


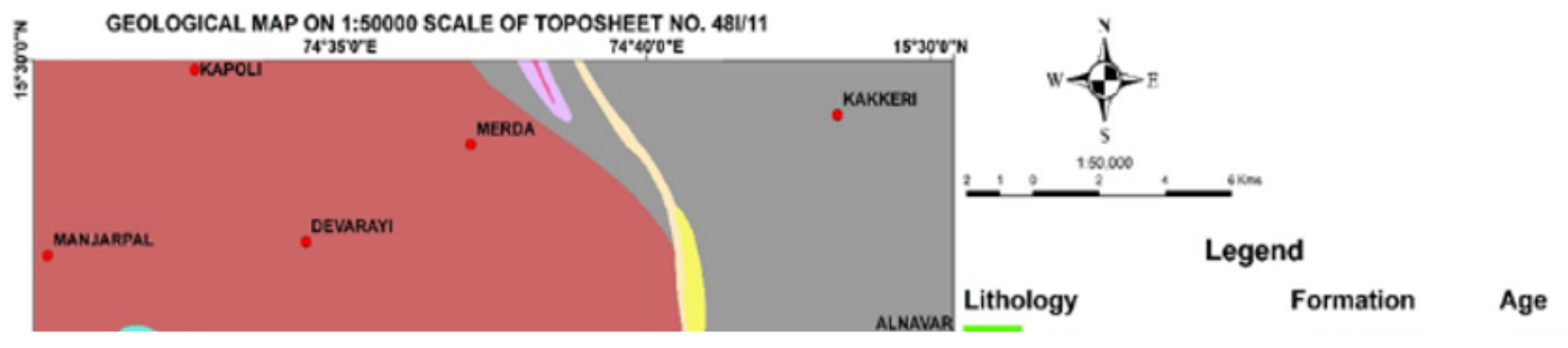

Figure 2

Geological map of the study area, Source: Bhat et al., 2021

\section{Figure 3}

Land-use land-cover map of the study area, Source: Bhat et al., 2021 
(a)

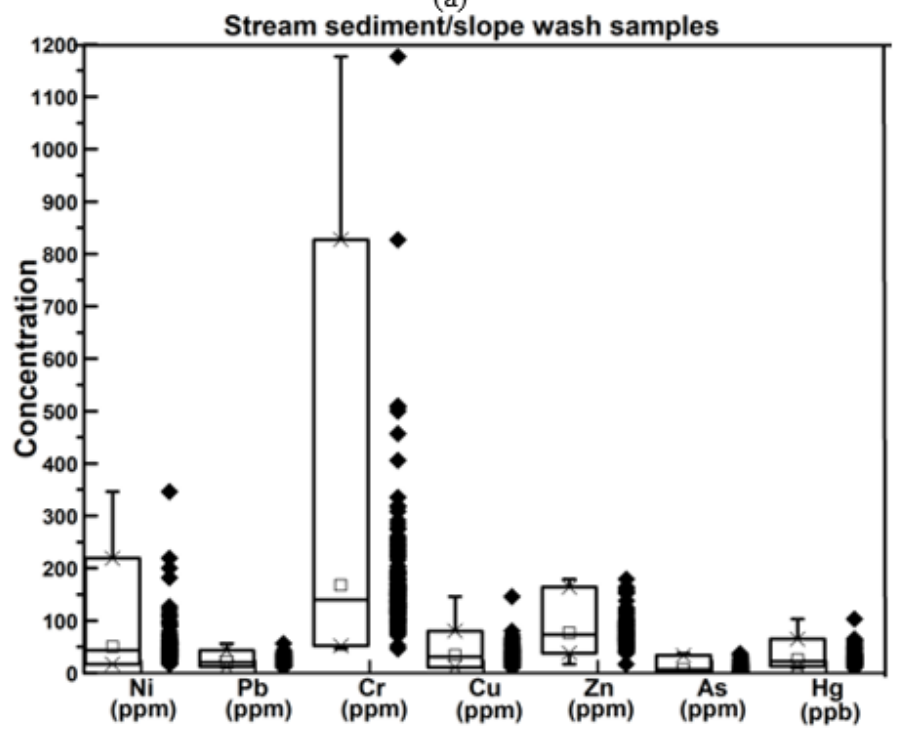

(b)

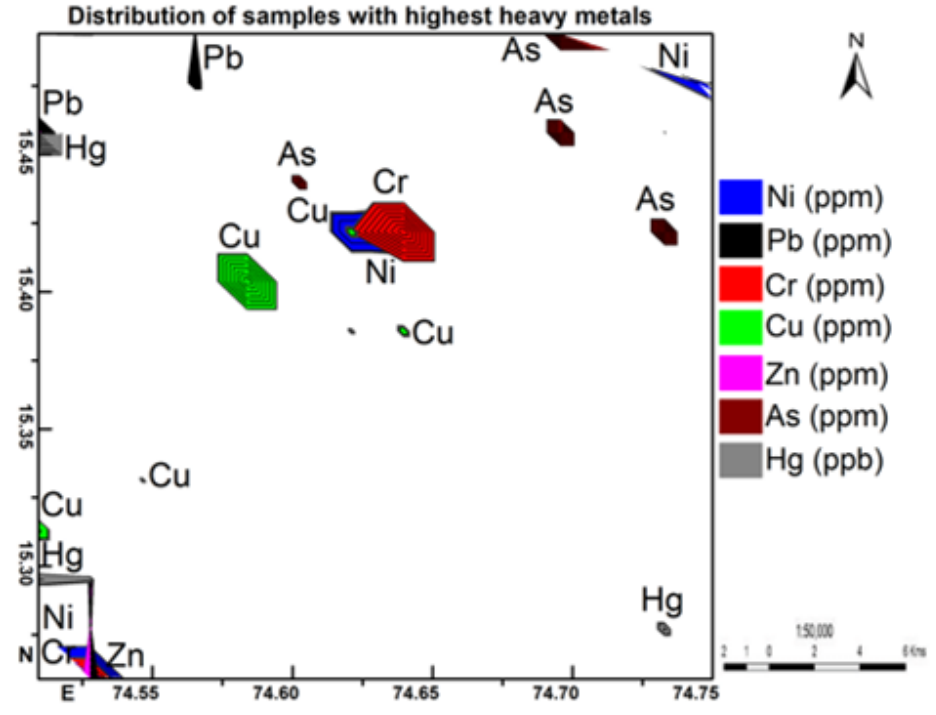

\section{Figure 4}

Heavy metal (a) concentrations in studied samples, and (b) distribution of samples with high metal content in the surface sediment samples of the study area.

Figure 5

(a) Enrichment factor of selected heavy metals, the spatial distribution of enrichment factors for (b) As and (c) $\mathrm{Cr}$ in the surface sediment samples. 


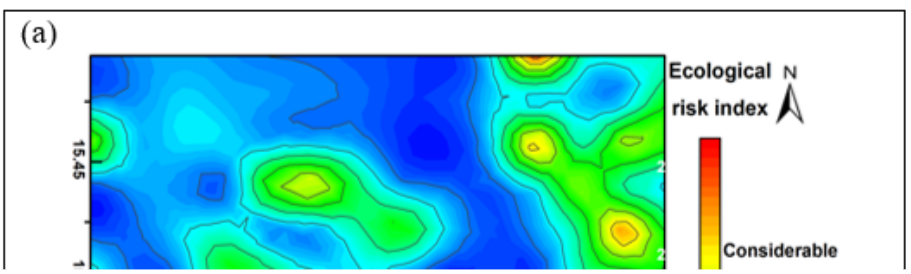

Figure 6

Spatial distribution of potential risks assessed by (a) ecological risk index, (b) toxic risk index, and (c) mean probable-effects-levels quotient methods. 
(a)

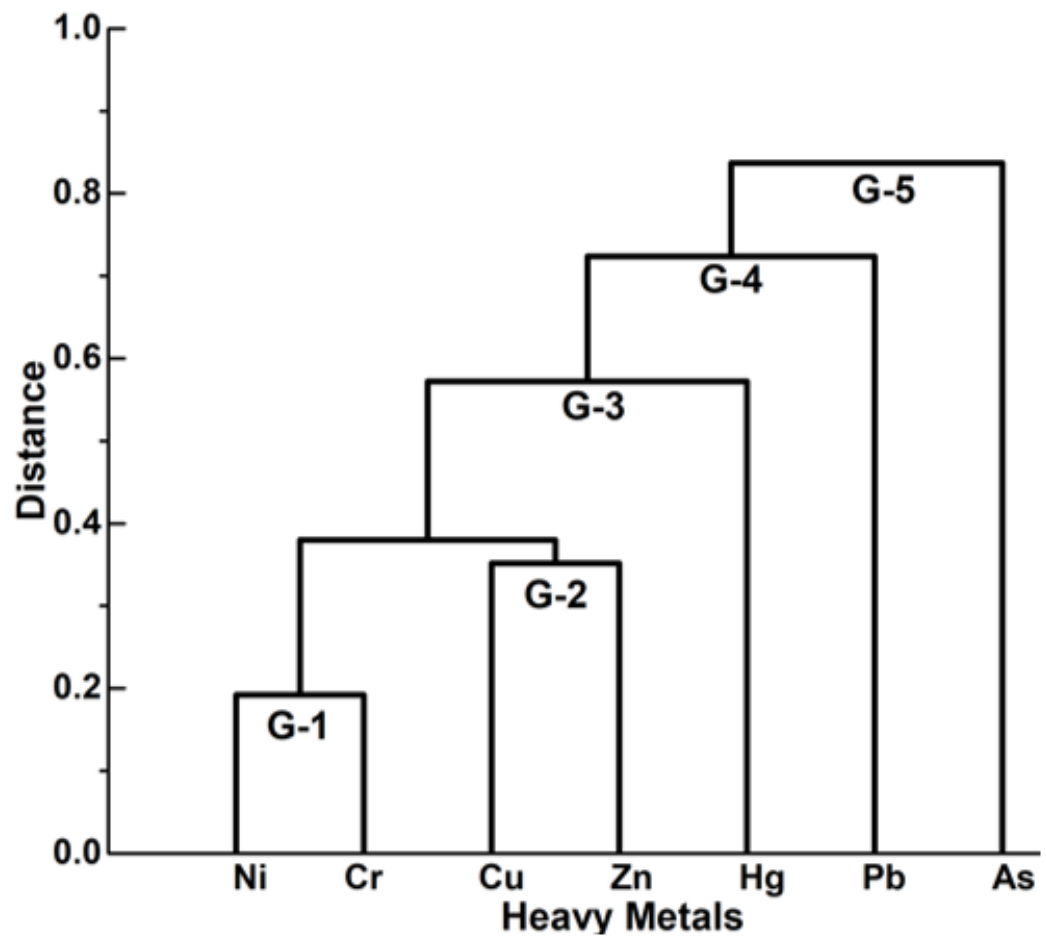

(b)

\begin{tabular}{|l|l|l|l|l|l|l|l|}
\hline & $\mathbf{N i}$ & $\mathbf{P b}$ & $\mathbf{C r}$ & $\mathbf{C u}$ & $\mathbf{Z n}$ & $\mathbf{A s}$ & $\mathbf{H g}$ \\
\hline $\mathbf{N i}$ & 1 & & & & & & \\
\hline $\mathbf{P b}$ & -0.10 & 1 & & & & & \\
\hline $\mathbf{C r}$ & $\mathbf{0 . 8 1}$ & -0.07 & 1 & & & & \\
\hline $\mathbf{C u}$ & $\mathbf{0 . 6 2}$ & -0.10 & 0.38 & 1 & & & \\
\hline $\mathbf{Z n}$ & $\mathbf{0 . 5 9}$ & 0.01 & 0.35 & $\mathbf{0 . 6 5}$ & 1 & & \\
\hline $\mathbf{A s}$ & 0.16 & -0.04 & 0.04 & 0.12 & 0.11 & 1 & \\
\hline $\mathbf{H g}$ & 0.26 & 0.28 & 0.05 & 0.28 & 0.43 & 0.03 & 1 \\
\hline
\end{tabular}

Figure 7

(a) Hierarchical cluster analysis and (b) Pearson's correlation matrix of selected heavy metals in the surface sediment samples used in this study.

\section{Supplementary Files}

This is a list of supplementary files associated with this preprint. Click to download.

- RawData.xIsx 